\title{
Title: The Social Origins of ESG? An Analysis of Innovest and KLD
}

\author{
Robert G. Eccles ${ }^{\mathrm{i}}$ \\ Linda-Eling Lee $\mathrm{e}^{\mathrm{ii}}$ \\ Judith C. Stroehle \\ - Accepted for publication in Organization \& Environment -
}

\begin{abstract}
This paper uses the study of two ESG data vendors - KLD and Innovest - to exemplify the "social origins of ESG" argument made by Eccles and Stroehle (2018). Based on in-depth interviews with the organizations' founders and historical document analysis, we recap the history of the cases and show how different origins, philosophies, and "purposes" of ESG shaped the methods and data characteristics of two of the most important data vendors of their time. We discuss why MSCI chose to continue with the financial value-oriented methodology of Innovest, while discontinuing the values-driven KLD. Through an in-depth literature analysis, we further show that not only the creation, but also the use of "non-financial performance" concepts rely on processes of social construction. We also find that investors use different ESG data than academics, potentially leading to misaligned narratives. Finally, with this paper we join the call for more explicit contextualization of ESG data, highlighting that both practitioners and academics need to better understand the social construction that underlies analyses which use different concepts of ESG.
\end{abstract}

\section{Introduction}

Demand for non-financial information has risen considerably over the last three decades. Already in the 1960s, this kind of information was used for socially responsible investment 
(SRI) strategies, challenging the traditional capital market's view which assumes that a company's responsibility is solely to its shareholders (Friedman, 1970), by seeking also to address values beyond financial returns. More recently, the investment community has acknowledged the financial value of environmental, social, and governance (ESG) issues and their associated risks (Amel-Zadeh, 2018), driving increased interest in ESG data. This shift in focus among investors, from values-driven SRI to a financial value-driven ESG (either instead of or in addition to a focus on values), has resulted in a surge of interest in ESG data. This has been supported by growing empirical evidence that links ESG and financial performance (Beal et al. 2017; Khan, Serafeim and Yoon, 2016; Eccles, Ioannou and Serafeim, 2014).

However, ESG is not a fixed concept beyond the combination of three important non-financial categories into one data source. In fact, there is considerable divergence in interpreting and using ESG information manifested in the ESG data vendor industry. Without a universally accepted definition of ESG metrics ${ }^{\text {iv }}$, each data vendor has developed its own methodology for measuring ESG, and their own set of indicators, to best capture their preferred conceptualization of materiality. Depending on the measurements and weights applied, assessments from different vendors of the same company's ESG performance may diverge. The result has been a complex ecosystem of ESG metrics, sources of data, and ratings which need correct contextualization to be interpreted and used successfully in analyses and investment decisions (Doh et al. 2010; Delmas et al. 2013; Chatterji et al. 2016). By contextualization we refer to the fact that each ESG metric has an idiosyncratic characteristic that is linked to methodological decisions made by both the creator and the user of the data. To correctly analyze, users need to have a good understanding of these decisions and how they potentially alter the comparison of results.

Eccles and Stroehle (2018) argue that it is especially due the "social origins" of data vendors which play a decisive role in how the meaning of ESG is constructed and, thus, why such 
metrics consequently diverge. The social origins argument links the organizational origins of data vendors (such as their country of origin, founders, original mission, and first clients) to the way how, due to these origins, ESG measures are differently assembled and infused with meaning or, in other words, how they are socially constructed ${ }^{\mathrm{v}}$. By analyzing how the diverse social origins of nine data vendors ${ }^{\text {vi }}$ led to diversity in the dimensions used to capture ESG, to multiple definitions of materiality, and to the specific service and product offers of each vendor they underline the importance of understanding ESG measures as a social construct.

In this paper, we seek to elaborate on the social construction argument made by Eccles and Stroehle (2018) with two explicit examples. First, we tell the stories of KLD ${ }^{\text {vii }}$ Research \& Analytics (KLD) and Innovest Strategic Value Advisors (Innovest), two of the oldest ESG data vendors, both of which were bought in a series of acquisitions to be ultimately owned by MSCI. Based on information from in-depth interviews with the founders of these organizations, we examine how and why the two original companies differed in terms of motivation, methods, and assessment. With this, we are able to trace how different origins and philosophies shaped the processes and results of two of the most important data vendors of their time. Furthermore, we tell how KLD and Innovest had to adapt and evolve their methodologies in the aftermath of their acquisition by RiskMetrics, in turn shaping MSCI's ESG offerings today. Secondly, we discuss how not only the creation, but also the use of ESG data is subject to social construction. By examining a list of 140+ academic articles which all use KLD data, we show that the use of ESG data in empirical studies also undergoes a process of construction, which - if not contextualized carefully - limits the comparability of results.

In order to effectively use ESG metrics, both investment professionals and academic researchers need to have a clear understanding of how data has undergone social construction. Our examples illustrate this social construction on the supply side, from KLD and Innovest, and its interpretation on the demand side by academic research. In doing so, we seek to inform 
data users about the importance of contextualization and the challenges of choosing, creating, and interpreting aggregate sources of ESG information.

\section{A Short History of ESG}

The concept of SRI has, just as notions of corporate social responsibility (CSR) and philanthropy, a much longer history than the term ESG. The inclusion of social considerations and restrictions into investment decision has existed since the nineteenth century, especially among faith-based organizations ${ }^{\text {viii }}$. Gaining momentum due to historical events, such as the Vietnam War, and social concerns, such as civil rights, the environment, and women's rights these issues were increasingly included into investment decisions of politically active individuals. Some decades later, SRI efforts specifically targeted investments in Apartheid South Africa and countries involved in arms-trade (such as Sudan) leading, for example, to the creation of the Ethical Investment Research Services Ltd. (EIRIS ${ }^{\mathrm{ix}}$ ) in London which was set up to provide independent research for churches, charities, and NGOs so they could make informed and responsible investment decisions ${ }^{\mathrm{x}}$.

The term ESG first appeared in a United Nations Global Compact (Global Compact) report on "Who Cares Wins - Connecting Financial Markets to a Changing World" in 2004 $4^{\mathrm{xi}}$, for which the former UN Secretary General invited a joint initiative of financial institutions "to develop guidelines and recommendations on how to better integrate environmental, social and corporate governance issues in asset management, securities brokerage services and associated research

functions" (UNGC 2004: p. 5). The final report was endorsed by a group of 20 financial institutions, including large banks (such as BNP Paribas, HSBC, and Morgan Stanley), asset owners (including Allianz SE and Aviva PLC), asset managers (such as Henderson Global Investors), and other stakeholders (such as Innovest). The United Nations Environmental Program's Finance Initiative's (UNEP-FI) “Freshfield Report," released only one year later in 
2005, gave first evidence on the financial relevance of ESG issues and discussed at length the concern of fiduciary duty in the use of ESG information in investment decisions ${ }^{\mathrm{xii}}$. The two reports are seen as the foundation ${ }^{\text {xiii }}$ of the UN-backed Principles of Responsible Investment ${ }^{\mathrm{xiv}}$ (PRI), which was launched in 2006 and has attracted global financial institutions as signatories that collectively represent more than U.S.\$ 89 trillion in assets ${ }^{\mathrm{xv}}$. The growth in signatories of PRI is a barometer of the growing awareness of ESG issues among investors and their inclusion in investment decisions (CFA, 2015). Figure 1 and 2 provide an overview of the growth of ESG investment funds and assets in the U.S. from 1995 - 2018 and globally from 2014 - 2018.

\section{[Insert Figure 1 and Figure 2 about here]}

As the increase in demand for ESG data has spurred the creation and growth of an entire industry of ESG data vendors in a relatively short period of time, those looking to use ESG data for the first time may find it challenging to navigate the wide range of offers available in the ESG data market. The former Global Initiative for Sustainability Ratings, for example, estimated that there are over 100 organizations collecting some form of ESG data ${ }^{\mathrm{xvi}}$, whereas other studies count about 500 ESG rankings (Branding Institute, 2016), 170 ESG indices (Lydenberg and White, 2015), 100+ ESG awards, and 120 voluntary ESG standards (Bowen, 2014; Mooij, 2017). For navigating a growing universe of ESG data and for understanding the dominant sources used for empirical ESG analysis, it is important for ESG data users to understand why and how ESG data sources differ in order to determine which is best for their own use. There are both conceptual and methodological reasons for these differences which are grounded in the social and contextual origins of data vendors. The following section will 
review some important theoretical concepts concerning the "social life" of measures, before discussing our cases and how social origins have shaped the creation and use of their ESG data.

\section{The Social Life of Measures}

There are a number of theories in sociology and economics that address how the use of information influences market activity, and how the creation of this information in turn influences the nature and scope of the activity created. The sociologies of knowledge and quantification, as well as the various streams of constructionism, particularly highlight how the process of creating knowledge is linked to social circumstance and the creation of an interpersonally accepted truth which serves, at least for a while, a social purpose (Berger and Luckmann, 1966). Measures, hereby understood as a quantified form of knowledge, are usually created to serve a specific purpose, either to document, track, or compare information. Once created, however, measures are socially distributed and can take on a life of their own. The socalled "reactivity" describes how quantification is "not merely a strategy for describing the social and natural worlds, but a means of reconfiguring them. It entails the imposition of new meanings and the disappearance of old ones" (Porter, 1994: 389).

In other words, the social life of measures is a two-way street: while the constructionist argument points out that we (our personality, socialization, belief systems, interactions, circumstance and so on) imprint on the character of the measures we create, the reactivity axiom postulates how the measures that we create then shape the world we live in. Any ranking serves as a good example: if of sufficient visibility, the criteria used to rank an organization (or person) will almost certainly influence its future activities (Espeland and Sauder, 2007). Such reactivity can be conscious, as certain aspects are actively managed to receive a higher score in the future. But reactivity is also unconscious, as described by the so-called Hawthorne Effect, which states that mere awareness of being observed can change one's behavior. 
The idea of performativity is also closely linked to this. Developed by Callon (1998), this concept describes how economic theory and language, for example used by prominent scholars, shape our economic system. Statements by economists or other social scientists are therefore "actively engaged in the constitution of the reality that they describe" (Callon, 2007: 318). While this thesis somewhat undervalues the importance of institutions, norms and social relations, it highlights how the traded belief and knowledge in organizational associations and professional networks is able to shape markets and the concepts which they work with (Beunza and Ferraro, 2018).

The concept and attached measurement of ESG, albeit without formal definition, is no doubt a powerful one. Today, investments of an estimated U.S.\$ 20 trillion in assets under management, approximately one quarter of all professionally managed assets globally ${ }^{\mathrm{xvii}}$, have been linked to some form of ESG data. And the growth of the ESG market shows that these ratings and rankings are likely impacting business' behavior which seek to address the ESG concerns of their shareholders and stakeholders.

However, the manifestation of ESG in market activities, or in other words its social purpose, is not uniform due to differences in investors' interests in SRI. Personal values and beliefs are often closely associated with the way ESG data is used in SRI investments (CFA, 2015). The purpose of ESG is therefore dual: While some investors have sought to address the negative externalities of companies and their unaddressed consequences for society and the environment ("values-driven investors"), others have instead or additionally adopted a more financiallyfocused position, viewing externalities as being mispriced in a world where companies will increasingly be required to internalize the cost of those externalities ("value-driven investors"xviii). For the latter, the inclusion of ESG information into investment decisions reflects a rational calculation of a more holistic and potentially more accurate evaluation of corporate value. 
These ideological differences also manifest in diverse definitions of 'materiality'. A concept from financial accounting which refers to information that an investor would find useful and without which they cannot make a proper investment decision ${ }^{\mathrm{xix}}$. The different conceptualizations of materiality applied to ESG which are most prominently referenced by companies and investors today are those of the Global Reporting Initiative (GRI) and the Sustainability Accounting Standards Board (SASB), respectively. Whereas SASB identifies material ESG issues for value-driven investment, at the industry level based on their relevance to each firm's financial performance ${ }^{\mathrm{xx}}$, GRI defines materiality as an externality, viewing as material that which reflects the organization's most significant economic, environmental, and social impacts ${ }^{\mathrm{xxi}}$.

\section{The Origins of KLD and Innovest}

The dual purpose of ESG has manifested in different data vendors, as the social origins of an organization influence the development of these characteristics (Eccles and Stroehle, 2018). In the literature, values-driven data vendors, such as KLD, are described as motivated by a profound belief in sustainable development ${ }^{\mathrm{xxii}}$ and have not traditionally focused on the concept of materiality, but came to use materiality as denoting issues that impact external stakeholders. ${ }^{\text {xiii }}$ Value-driven data vendors, such as Innovest, are interested in the fact that ESG information is financially relevant and material issues are thus defined according to their relevance in creating corporate value and shareholder returns ${ }^{\mathrm{xxiv}}$.

To understand the social origins of both organizations, we conducted a historical document analysis and led in-depth, semi-structured interviews with the founders of both KLD and Innovest to be able to better contextualize the evidence we found. Table 1 lists the people we interviewed. Based on the gathered data, the following is a short history of both organizations.

[Insert Table 1 about here] 
KLD Research \& Analytics, Inc. (KLD) - formerly known as Kinder, Lydenberg, Domini \& Co. - was founded in Boston in 1988 with the mission ${ }^{\mathrm{xxv}}$ to "remove barriers to socially responsible investing, [and] provide superior research and support services to the socially responsible investment market" and the purpose to "influence corporate behavior toward a more just and sustainable world". With an advocacy attitude and focusing largely on institutional investors in the U.S. market, KLD rapidly grew into one of the most important SRI data vendors, and soon expanded its assessments to include international markets, long before the notion of ESG even existed. By 2007, several institutional money managers worldwide were using KLD's Socrates product and other research to integrate what had by then become known as ESG factors into their investment decisions. ${ }^{\text {xxvi }}$ Companies were originally assessed on eight dimensions: community relations, employee relations, environment, product, treatment of women and minorities, military contracts, nuclear power, and South Africa. ${ }^{\text {xxvii }}$ For each of the first five dimensions, companies were scored on a fivepoint scale from "major strength" to "major weakness" (renamed to "concerns" after 1998), and on a solely negative scale for the last three dimensions (Graves and Waddock, 1994). These dimensions were later altered to focus on the following: environment (including climate change and operations management), community, corporate governance, diversity, employee relations, human rights, and product quality and safety. ${ }^{\mathrm{xxviii}}$

Always committed to its roots in the values-based assessments, KLD's strengths and weaknesses evaluations intentionally did not provide an aggregate score for companies ${ }^{\mathrm{xxix}}$. This forced investors to consciously construct their own rating, infused with their own values, when using KLD data. KLD's method was largely consistent in terms of metrics collected across industries. Data collection deliberately focused on issues where company independent information was available. For issues where this was not possible, corporate self-disclosure was used with a narrative-based approach to scoring. 
KLD's rating framework considered a wide range of stakeholders and defined a full list of controversial issues (nuclear energy, weapons sale, pollution, etc.) to be considered in its ESG assessments. Its methodology favored corporations with strong stewardship of the environment, devotion to serving local communities, high labor standards, and high quality and safety of products: "KLD's analysis combines an awareness of the overarching impact companies can have on social and environmental conditions with sensitivity to the challenges faced by businesses operating in different sectors of the global economy. KLD therefore rates companies on both how they address the ESG challenges within their industry and how they treat all stakeholders ${ }^{\mathrm{xxx}}$ ". Hence, KLD focused its ESG assessment specifically on the benefit or harm to the wider society and not on the financial benefit of investors. Even though its index (Domini Social Index 400) outperformed the S\&P 500 in seven of the first 10 years $^{\mathrm{xxx}}$, their credo was always to focus on social and environmental performance, rather than financial outperformance.

Innovest Strategic Value Advisors, Inc. (Innovest) was created as an environmental investment research advisory firm with headquarters in New York and Toronto, with later offices in London and Paris (2006). ${ }^{x x i i}$ The company's founder, Dr. Matthew Kiernan, laid the foundation of the company in 1992 due to his previous work and frustrations as a partner at KPMG and his experiences as a director at the World Business Council for Sustainable Development (Kiernan, 2009). Convinced that true systems change needs the financial system on board, Innovest was created as a "green analogy" to Moody's. Joining in 1995, co-founder Hewson Baltzell, coming from a career in real estate finance at Lehman Brothers and JPMorgan Chase, helped advocate for the link between environmental and financial performance ${ }^{\mathrm{xxxiii}}$, describing "the brink of an 'Eco-Industrial Revolution' - a worldwide industrial restructuring in which companies' 'eco-efficiency' and environmental performance are becoming far more critical to 
their competitiveness, profitability, and even survival". ${ }^{x x i v}$ With this maxim in mind, the Innovest methodology was all about teasing out an eco-friendly view of management quality.

In its first three years, the company provided industry environmental performance reports focused on chemicals, petroleum, and forestry products. With a quantitative methodology for its flagship product, the "EcoValue'21" environmental screening, and a strong focus on financial materiality, Innovest was able to quickly convince big players in the financial industry to become clients, including five Fortune 100 companies, a top 10 global insurer, and two of the world's largest asset managers in their client portfolio by $1998^{\mathrm{xxx}}$. In 2004, Innovest launched a new flagship product, the Intangible Value Assessment (IVA), which was developed in cooperation with strategic partners such as Pricewaterhouse Coopers and Morgan Stanley Asset Management ${ }^{\mathrm{xxxvi}}$. In the IVA rating framework, over 50 individual performance indicators were assessed in five areas (strategic governance, emerging markets, products and services, human capital, and stakeholder capital) to arrive at an overall environmental and sustainability performance score within a given sector. The methodology aimed to be as quantitative as possible, and models were informed by direct conversation with companies where possible. Later, once the scope of assessments was too big to allow for individual company conversations, data sources beyond corporate self-disclosure were used to assess companies that failed to disclose sustainability information. Ratings were modeled after bond ratings using a AAA (best) to CCC (worst) rating scheme $\mathrm{xxxvii}^{\text {. }}$

"Intangible value" was defined as driven by four main clusters of non-financial assets which

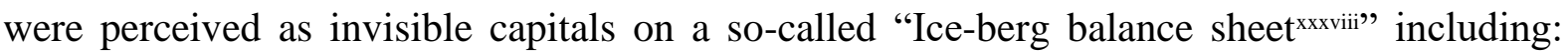
"EcoValue" (measured by the EcoValue'21 screening), human capital, stakeholder capital, and strategic governance. These four areas were the focus of all Innovest investment research. With its IVA ratings, Innovest sought to move beyond the negative screens and values-focused assessments of most SRI strategies, embracing instead the goal of demonstrating the financial 
superiority of high performers in its IVA and EcoValue ratings ${ }^{\mathrm{xxxix}}$ to actively drive the mainstreaming of non-financial value consideration (Kiernan, 2009: 4). By 2005, Innovest had over U.S.\$ 1 billion under sub-advisory mandates, including partnerships with ABN-AMRO, Brown Brothers Harriman, Schroders, State Street Global Advisors, and others ${ }^{\mathrm{xl}}$.

\section{From Innovest and KLD to MSCI}

In 2009, Innovest (February) and KLD (November) were both acquired by RiskMetrics, a risk management and corporate governance company which was created in 1994 out of J.P. Morgan's internal value-at-risk program ${ }^{\mathrm{xli}}$. They were the last two in a series of acquisitions by RiskMetrics, which also included Institutional Shareholder Services, Inc. ${ }^{\text {xli }}$ (ISS) and the Center for Financial Research and Analysis ${ }^{x l i i i}$ (CFRA) (full history in Table 2).

\section{[Insert Table 2 about here]}

When Innovest joined RiskMetrics, they significantly enlarged a small team that had already been working on environmental and social assessments (E\&S) within ISS, which originated from their 2005 acquisition of the Investor Responsibility Research Center. With the acquisition of KLD just 10 months later, RiskMetrics now owned what were two of the largest ESG research providers at that time, and a significant share of the market for this data. However, what may seem like an advantage in the market created internal challenges for RiskMetrics, and soon after MSCI.

Although KLD and Innovest might have appeared very similar from the outside, with seemingly close product offerings and even clients, the two companies were in fact quite different, on both a conceptual and practical level. Conceptually, the organizations had been built on the basis of a very different understanding of ESG, leading to different definitions of materiality and varying methodologies for making their assessments. On the practical side, for the implementation of these methodologies, the companies had also been managed and 
organized differently. As is often the case in merger integration, it quickly became evident that diverse teams had their own organizational structures and products that required different processes of data collection, aggregation, and analysis. Innovest, for example, was built on the idea of different ESG exposure levels at different industries, therefore varying the effort in collecting data for each. KLD, on the other hand, took a systems-view approach, choosing issues of universal importance across industries with a focus on society, not corporation.

Data was also contextualized differently. Innovest's industry-focus meant that scores were normalized to show a company's relative ranking within its industry. The so-called best-inclass assessments are a typical example of this. KLD's assessments, on the other hand, were absolute. This meant that companies' environmental and social footprints were measured and reported in an absolute way, regardless of industry. The approach to report absolute instead of relative impacts was closely linked to KLD's advocacy mindset. Comparison was not the goal, but rather the capture of what we would call "corporate externalities" today. For Innovest, on the other hand, the capacity to compare was key. Given that larger companies have larger footprints, Innovest normalized the data to have industry rankings that took different sizes into account. The relative performance to industry peers was consequently seen as more important for financial analysis than the reporting of an absolute footprint.

When RiskMetrics was acquired by MSCI in 2010, the company sought to combine the two data companies in an effort to keep "the best of both worlds," creating one set of data with one set of data collection processes. This project took almost one year and required a revision of all data collection and aggregation processes, methodologies, and analytical procedures of each organization. At the same time, however, MSCI was facing a growing market demand for ESG data with a financial materiality-driven rationale, which also demanded higher data coverage (number and geographic scope of companies assessed) for reliable benchmarking. In light of this market development, and after revision of all processes, MSCI decided that the Innovest 
method was superior for two reasons. First, it was the product that most closely met its clients' needs for financially-focused assessments. Second, its approach to collecting industry-specific information was likely easier to scale quickly to meet the growing demand of the market, as effort was minimized in collecting and analyzing ESG data that are deemed immaterial to a given industry. MSCI finally decided against a merger of methodologies and instead kept Innovest's IVA as the core methodology on which to build what today is known as MSCI ESG Ratings. It should also not be underestimated that Innovest was acquired by RiskMetrics before KLD, which helped the decision makers at the time to favor Innovest.

While some elements of KLD's data were incorporated into MSCI's wider ESG offering, such as its datasets that support negative screening and assess corporate controversies, KLD's ESG assessment began to be withdrawn from the market. Internal reorganization of teams and processes were made, and clients using KLD's ESG assessments were gradually transitioned to IVA Ratings. From 2010 onwards, data collection to support KLD's ESG assessment framework effectively ceased. However, because of the importance of longitudinal data to the academic community, MSCI continued to produce KLD-like assessments based on the data collected for its ESG Ratings. Through an automated mapping process, MSCI's ESG Ratings are linked to the original KL dimensions of strengths and weaknesses. It is important to highlight that the KLD-like assessments are mapped from data collected for other ESG data products and not specifically for the KLD assessments. Due to the changes in data collection, this "new" KLD data is therefore not directly comparable with historical KLD data from before 2010. MSCI explicitly denotes this in its MSCI KLD STATS Methodology document. ${ }^{\text {xliv }}$

\section{Academic Social Constructions of ESG Ratings}

Since it was first used for an article in 1994 by Graves and Waddock, the KLD Socrates database, which includes KLD's social and environmental assessments of roughly 8,000 
companies from 1991 to $2011^{\mathrm{xlv}}$, and as supported by MSCI in an adapted version since then, has become one of the most used resources for the measurement of corporate social responsibility $^{\text {xlvi }}$ (CSR) for articles published in academic journals. Studying how a database becomes accepted as a universal resource in the academic community, Gond et al. (2018) accumulated a set of 572 journal articles, published between the years 1994 and 2016, which either worked with or referred to the KLD database as an indicator of CSR. Even by only compiling the articles listed on the first ten pages of Google Scholar under the search term "KLD dataxlvii", we were able to make a list of 141 articles which either used the KLD data in academic analysis (about $80 \%$ ) or mentioned it in a theoretical discussion (about 20\%, e.g., on how the concept of CSR should be constructed and measured). ${ }^{x l v i i i}$ Figures 3 and 4 provide descriptions of the compiled articles (further ones can be found in Appendices 1 and 2).

\section{[Insert Figure 3 and Figure 4 about here]}

We find that most of these articles were published in management, business ethics, and finance journals. The journal with the most articles using KLD data is the "Journal of Business Ethics" (29 articles), followed by the journal "Business and Society" (10), the "Strategic Management Journal" (9), and the "Academy of Management Journal" (7) ${ }^{\text {xlix }}$. All of these journals have a medium to high impact factor ${ }^{1}$, indicating that they have a relatively high readership and citation rate within the academic community. In terms of research interest, we find that from 1994-2014, 55-65\% of articles focused on the relationship between financial and non-financial performance and "CSR and management" (see elaboration on topics in Table 3).

\section{[Insert Table 3 about here]}

As described above, KLD provided assessments for eight different dimensions intentionally without creating an aggregate measure of ESG performance. The deliberate choice of KLD to not provide an overall aggregate ESG measure has forced each researcher using the data to 
devise his or her own aggregate measure of corporate ESG or CS performance. It is not always clear to reviewers and readers of these academic studies that each and every instance of an aggregate measure created out of KLD data is hence an act of social construction by the individual researcher and does in fact not express an unfiltered KLD view of the overall ESG performance of a company. If explicitly described in the research paper, there is nothing inherently wrong with this construction. However, with the popularization of KLD data as a measure of CSR in the academic community, we find that a diverse set of aggregate measures based on KLD data has emerged. Gond et al. (2018) show that in the early years (1994 - 1999) mostly aggregate measures of the KLD data were used, whereas from 2000 onwards, scholars started disaggregating the KLD dimensions again, focusing on the dimensions which best fit their research interest. In 2006, two semi-aggregate measures became prominent in the use of KLD when Mattingly and Berman (2006) performed an exploratory factor analysis on the KLD data, uncovering two major patterns amongst KLD indicators to which they referred as

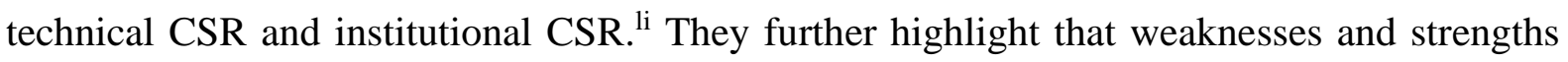
should remain separate in analyses, as they strongly load onto different factors.

Clearly, care should be taken in comparing these studies with each other, a hallmark of academic research, since exactly what is meant by the "KLD indicator" varies by study. While each study must stand on its own merits in making the case regarding a relationship between financial and non-financial performance - the focus of most of them and a topic of growing interest - the frequently cited independent variable of "non-financial performance" is not commonly defined across studies. This contrasts with studies on financial performance, which relies on several well-defined and universally recognized concepts.

To exemplify the diversity of users of KLD data, Table 4 summarizes the methodology and findings of four studies, all assessing the link between non-financial and financial performance in different settings, but all using different methods of aggregation for the measure of non- 
financial performance which relies on KLD data. Findings from these studies cannot strictly be compared, at least not without proper contextualization.

\section{[Insert Table 4 about here]}

Illustrating the importance of contextualization, a meta-study of Orlitzky (2011) shows that differences in results ${ }^{\text {lii }}$ about the relationship between non-financial and financial performance vary depending on the discipline of the journal that an analysis was published in (management vs. finance outlets). This shows that not only methods, but also knowledge and interpretation are socially constructed in editorial and peer review processes (Gond et al. 2018).

To address this issue, several academics have made efforts to test the "construct validity" of KLD data, triangulating it with other non-financial data to verify whether it actually measures what it is prominently used for (Sharfman, 1996; Griffin and Mahon, 1997; Rowley and Berman, 2000; Chatterji et al. 2009; 2016). And whereas Wood and Jones (1995) have criticized the KLD database as "numerically crude" for making qualitative judgements, the same paper still declares it the "best-researched and most comprehensive" database for social and environmental performance. Others agree that "the benefits derived from the KLD database far out-weigh the problems associated with it" (Ruf et al. 2001).

Let us repeat the point we made above: there is nothing inherently wrong with using socially constructed aggregate measures as long as the researcher explains his or her social construction process and the underlying reasons for why this particular approach was taken. Many academics fail to make this explicit. A study that uses explicitness and contextualization well in the social construction of its measures is Khan et al.'s (2016) mapping of KLD measures to SASB. The paper's intent reveals an obvious need for selection of sense-making in the construction of its methodology, but it is explicit and explanatory about this at every critical juncture of the process. 
Non-explicit activities of social construction in the study of non-financial performance have been criticized especially by authors such as Chatterji et al. (2009), Gond and Crane (2010), and Gond, et al. (2018). All argue that data construction, without proper method, argumentation, and contextualization harms generalizability of findings about non-financial performance. "Instead of relegating the work of data construction to the shadows of the review process, we suggest scholars make the process by which datasets are imported more 'public' and engage with the practitioners who produce data as a step toward enhancing quality" (Gond et al. 2018: p.6). In including this example of social construction in our paper, we join the call for a more rigorous process of qualitative assessments of quantitative measures and for the related contextualization of findings, if such measures are used.

\section{Discussion}

The two examples we give in this paper show how both the creation and the use of ESG data undergoes several stages of social construction, and how important it is to correctly contextualize non-financial analyses based on ESG. Our cases also tell a story about the varying purposes of ESG, how these have evolved over time, and how they are still evolving.

In the first part, we recount the histories of KLD and Innovest, highlighting how different two organizations can be despite offering what might appear to be similar products. Diverse conceptual standpoints (one values-based, the other value-based) led to different practical processes such as measurement and data collection and catered to different audiences. In the end, it was the market demand for ESG data with higher coverage, consistency, and financial materiality that led to the continuation of the Innovest rating instead of the KLD assessments. At its very core, however, the case of the failed integration of the KLD and Innovest assessments is a testament for how powerful the social origins of ESG measures can be, in this case inhibiting the combination of two organizations because they were too different. 
Three observations made in this paper highlight why differences in methodology and contextualization of ESG data should be considered by data users. First, neither the original KLD data, nor the MSCI-reproduced KLD-like assessments have ever included an aggregate score. All academics that use an aggregate score based on KLD data in their analyses go through a process of socially constructing the score. Without contextualization, or an explicit discussion of this construction and its implications, comparability of studies is obscured, and measures may be too abstract to offer practical insights or inform the investment community.

Second, because there is a break in the KLD assessment creation in 2011, with a significant change in data assembly and assessment methodology, the use of data across that point would be methodologically flawed if not addressed appropriately with yearly fixed-effects or further robustness tests ${ }^{\text {liii }}$. Lacking awareness of such changes highlights that data use without data contextualization can cost credibility of academic findings.

Third, already since 2011, the methodology of Innovest has now been used as the basis for MSCI's ESG Ratings and the assessments of KLD, available only for academic researchers (now known as MSCI KLD STATS), exist only as a mapped version. This means that since then, investment professionals using MSCI's ESG Ratings have exclusively been using ratings built on the Innovest IVA rating framework, while academics have continued to use the assessment of KLD for their analyses. While each world - that of academia and that of investing - can obviously stand for itself, the diversity of data used in these different discourses is potentially problematic when academic studies are used to support ESG integration by investors. It is encouraging that both sets of data yield similar high-level findings about the positive relationship between non-financial and financial performance. However, when an academic study is used to inform an investment strategy, the investor needs to be sure to understand the definitions and measures of ESG factors which are used. 
Finally, the story of our cases highlights an interesting progression of the use of ESG and its reactivity in the capital market through shifting purposes. KLD and Innovest clearly worked with different premises: While Innovest's purpose for ESG was financial from the beginning, KLD's data was never designed to drive financial performance. Even though its index outperformed for many years, the argument was never that investors should use KLD to make money, but rather, that they should choose well-performing companies to evoke system transformation. This difference in premise and purpose essentially appealed to two very different degrees of ESG-readiness on the market. While the use of KLD required an informed decision on how to aggregate the data, Innovest didn't require such judgement calls. Yet, it wasn't laziness that favored Innovest's methodology and drove its success at the time. It was the reality of the market, which was new to questions of social and environmental impact measurement and insecure about related judgement calls. It was therefore much easier to buy into a financial upside argument and a methodology that didn't require much additional reflection, than to buy into ESG data and framing which would have required conversations within organizations which they were not ready to have. It is this buy-in that made ESG credible and allowed it to enter the mainstream in investment practice.

However, the reactivity of ESG measures has manifested through an education of the market and investors and the demand for data has gone full circle: Today, many users of ESG find the financial upside argument not good enough anymore. Particularly in view of system level "wicked" problems, such as climate change and income inequality, investors want to understand the social and environmental impact of their portfolios and demand the measurement of externalities beyond non-financial performance measures. This is in some way ironic, as the core idea of KLD catered exactly to this demand. Also, the intentional offer of disaggregated KLD scores can be associated with a prominent current discussion: the question of whether there should be a single bottom line to environmental and social assessments and 
whether positive externalities should outweigh negative ones. The disaggregation trend we find in many efforts among the more serious of today's sustainable funds highlights this mentality.

The fact that KLD fell "victim" to the much stronger ESG financial-value trend of the early 2000s shows how important the reactivity of ESG measures was: the recognition of the financial "value-driven" mindset of ESG was necessary to expand the sustainable investing market to the mainstream it is today. As sustainable investing is on the brink of achieving the buy-in even from the largest of investors, the market seems to go "back to the future": the increased recognition of system-level issues drives the demand beyond financial value, however not necessarily back into the SRI / values-driven data space, but rather into a new space of impact measurement and credibly capturing corporate externalities.

Still, it is difficult to generalize a 'values' to 'value' to 'systems-thinking' time progression for all actors in the investment chain. There is a much more nuanced understanding now than a few years ago about the time horizon mismatch between different players in the investment value chain. For example, universal owners with perpetual time horizons are the most vocal about the importance of having an extra-financial impact on society. But for them, those 'extrafinancial' risks will be internalized financially, hence there isn't much of a gap between financial and non-financial given enough time. On the other hand, they pay their external investment managers to manage to one to three-year horizons at best, so the investment managers have to treat the systemic, non-financial impact either as compliance (client demand), or as something they 'believe' in, such as values or reputation.

\section{Conclusion}

The examples in this paper highlight the importance of understanding all underlying assumptions when speaking about ESG. First, the case of the failed integration of KLD and Innovest we present is a testament for the power which social origins yield over the 
development of ESG measures. The differences between the organizations made integration so difficult that it never happened. Second, the discussion of KLD highlights that ESG data used in analyses should always be contextualized, with every decision and critical juncture of construction made explicit, in order to be understood correctly by the audience of that analysis. Since social construction does not only take place at the data creation, but also at the data user stage, core concepts of ESG investing need to be revised with care.

The insights of the discussion of social construction, contextualization, and sense-making in the use of ESG origins leads us to believe that there are many more areas where these questions should be asked. Especially in the investment community, where ESG data is used every day, how (if) is ESG interpreted and understood? Without a universal understanding of the concept, what do we accordingly mean by ESG integration? And what language is used in situations of interaction, such as ESG engagement? In the core of the debate about ESG, there is also still a lack of understanding about the different motivations of diverse users of this data. In order to ensure that conversations take place with a shared understanding of what we mean with different buzz-words, such as ESG integration, further studies on the creation of meaning and language at the ESG user level will be required. 


\section{Bibliography}

Amel-Zadeh, A. (2018) Social Responsibility in Capital Markets: A Review and Framework of Theory and Empirical Evidence. Working Paper, Said Business School, Oxford.

Beal, D.; Eccles, R.; Hansell, G.; Lesser, R.; Unnikrishnan, S.; Woods, W. and Young, D. (2017) BCG Total Societal Impact study. A new Lens for Strategy. Boston Consulting.

Berger, P. L. and Luckmann, T. (1966) The Social Construction of Reality. A Treatise in the Sociology of Knowledge. Doubleday: New York.

Beunza, D and Ferraro, F. (2018) Performative Work: Bridging Performativity and Institutional Theory in the Responsible Investment Field. In: Organization Studies, Vol. 40(4): 515-543.

Bowen, F. (2014) After Greenwashing: Symbolic Corporate Environmentalism and Society. Cambridge University Press: Cambridge, UK.

Branding Institute (2016) Ranking of the Rankings. Available from https://www.branding--institute.com/rating---the---rankings/ranking---of---the---rankings, accessed Aug 2018

Burchell, S.; Clubb, C.; Hopwood, A.; Hughes, J. and Nahapiet, J. (1980) The Roles of Accounting in Organizations and Society. In: Accounting, Organizations and Society. Vol. 5(1): 5-21.

Callon, M., ed. (1998) The Laws of the Markets. Oxford: Blackwell, Oxford, UK.

Callon, M. (2007) What does it mean to say that economics is performative? In: D. A. MacKenzie, F. Muniesa, \& L. Siu (Eds.), Do economists make markets? On the performativity of economics. Princeton, NJ: Princeton University Press.

Chatterji, A., R. Durand, D. Levine, and S. Touboul (2016) Do Ratings of Firms Converge? Implications for Managers, Investors and Strategy Researchers. In: Strategic Management Journal, Vol. 37: 1597-1614. 
Chatterji, A., D.I. Levine, and M.W. Toffel (2009) How Well Do Social Ratings Actually Measure Corporate Social Responsibility? In: Journal of Economics and Management Strategy. Vol. 18(1) 125-169.

CFA Institute (2015) Environmental, Social and Governance Issues in Investing. A Guide for Investment Professionals. Center for Financial Analysis, London.

Delmas M, Etzion D, Nairn-Birch N. 2013. Triangulating environmental performance: what do corporate social responsibility ratings really capture? In: Academy of Management Perspectives, Vol. 27(3): 255-267.

Doh, J. P., Howton, S. D., Howton, S. W., \& Siegel, D. S. (2010). Does the market respond to an endorsement of social responsibility? The role of institutions, information, and legitimacy. In: Journal of Management, Vol. 36(6): 1461-1485

Eccles, R. G., I. Ioannou, and G. Serafeim (2014) The Impact of Corporate Sustainability on Organisational Processes and Performance. In: Management Science, 60: 2835-2857.

Eccles, R. G. and Stroehle, J. C. (2018) Exploring Social Origins in the Construction of ESG Measures. Working Paper, Oxford University. https://papers.ssrn.com/sol3/papers.cfm? abstract_id=3212685

Espeland, W. N. and Sauder, M. (2007) Rankings and Reactivity: How Public Measures Recreate Social Worlds. In: American Journal of Sociology. Vol. 113(1): 1 - 40.

Friedman, M. (1970) The social responsibility of business is to increase its profits. New York Times Magazine, September 13.

Gond J-P., Vigneau, L. and Johnson-Cramer, M. (2018) How do measures become academically acceptable? A case study of the Kinder Lydenberg and Domini (KLD) Database. In: Academy of Management Proceedings, Vol. 2018 (1). 
Gond, J-P. and Crane, A. (2010) Corporate Social Performance Disoriented: Saving the Lost Paradigm? In: Business \& Society, Vol. 49(4): 677 -703.

Graves, S. B. and Waddock, S. A. (1994) Institutional Owners and Corporate Social Performance. In: Academy of Management Journal 1994, Vol. 37(4): 1034-1046.

Griffin, J. and Mahon, J. F. (1997) The corporate social performance and corporate financial performance debate: Twenty-five years of incomparable research. In: Business and Society, Vol. 36(5): 5 - 31 .

Khan, M. and Serafeim, G. and Yoon, A. (2016) Corporate Sustainability: First Evidence on Materiality. In: The Accounting Review, Vol. 91(6): 1697-1724.

Kiernan, M. J. (2009) Investing in a Sustainable World. Why Green is the New Color of Money on Wall Street. AMACOM, New York.

Lydenberg, S. and A. White (2015) Responsible investment indexes. Origins, nature and purpose. in the Routledge Handbook of Responsible Investment. Eds. T. Hebb, et al. Routledge: New York, NY.

Mattingly, J. E. and Berman, S. L. (2006) Measurement of Corporate Social Action Discovering Taxonomy in the Kinder Lydenberg Domini Ratings Data. In: Business \& Society, Vol. 45(1): 20-46.

Mooij, S. (2017) The ESG Rating and Ranking Industry: Vice or Virtue in the Adoption of Responsible Investment? In: Journal of Environmental Investing, Vol. 8(1): 331 - 351.

MSCI Research Inc. (2017) MSCI ESG KLD STATS: 1991-2016 Data sets Methodology. MSCI ESG Research, New York. 
Orlitzky, M. (2011) Institutional logics in the study of organizations: The social construction of the relationship between corporate social and financial performance. In: Business Ethics Quarterly, Vol. 21(3): 409-444.

Porter, T. M. (1994) Making Things Quantitative. In: Science in Context. Vol. 7(3): 389 - 407.

Richardson, A. J. (1987) Accounting as a legitimating institution. In: Accounting, Organizations and Society, Vol. 12(4): 341-355.

Rowley and Berman (2000) A brand new brand of corporate social performance. In: Business and Society, Vol. 39(4): $397-418$.

Ruf, B., Muralidhar, K., Brown, R. M., Janney, J. J. and Paul, K. (2001) An Empirical Investigation of the Relationship Between Change in Corporate Social Performance and Financial Performance. In: Journal of Business Ethics, Vol. 32: 143-156.

Sharfman M. (1996) The construct validity of the Kinder, Lydenberg and Domini social performance ratings data. In: Journal of Business Ethics, Vol. 15(3): 287-296.

United Nations Global Compact (2004) Who Cares Wins. Connecting Financial Markets to a Changing World. United Nations, Geneva.

United Nations Environment Programme Finance Initiative (2005) Freshfield Report. A legal framework for incorporating environmental, social and governance issues into institutional investment. Freshfields Bruckhaus Deringer, London.

Wood, D. J. and Jones, R. E. (1995): Stakeholder Mismatching: A theoretical problem in empirical research on corporate social performance. In: The International Journal of Organizational Analysis, Vol. 3(3): 229 - 267. 
Figure 1: Investment Funds incorporating ESG 1995 - 2018, US SIF Foundation

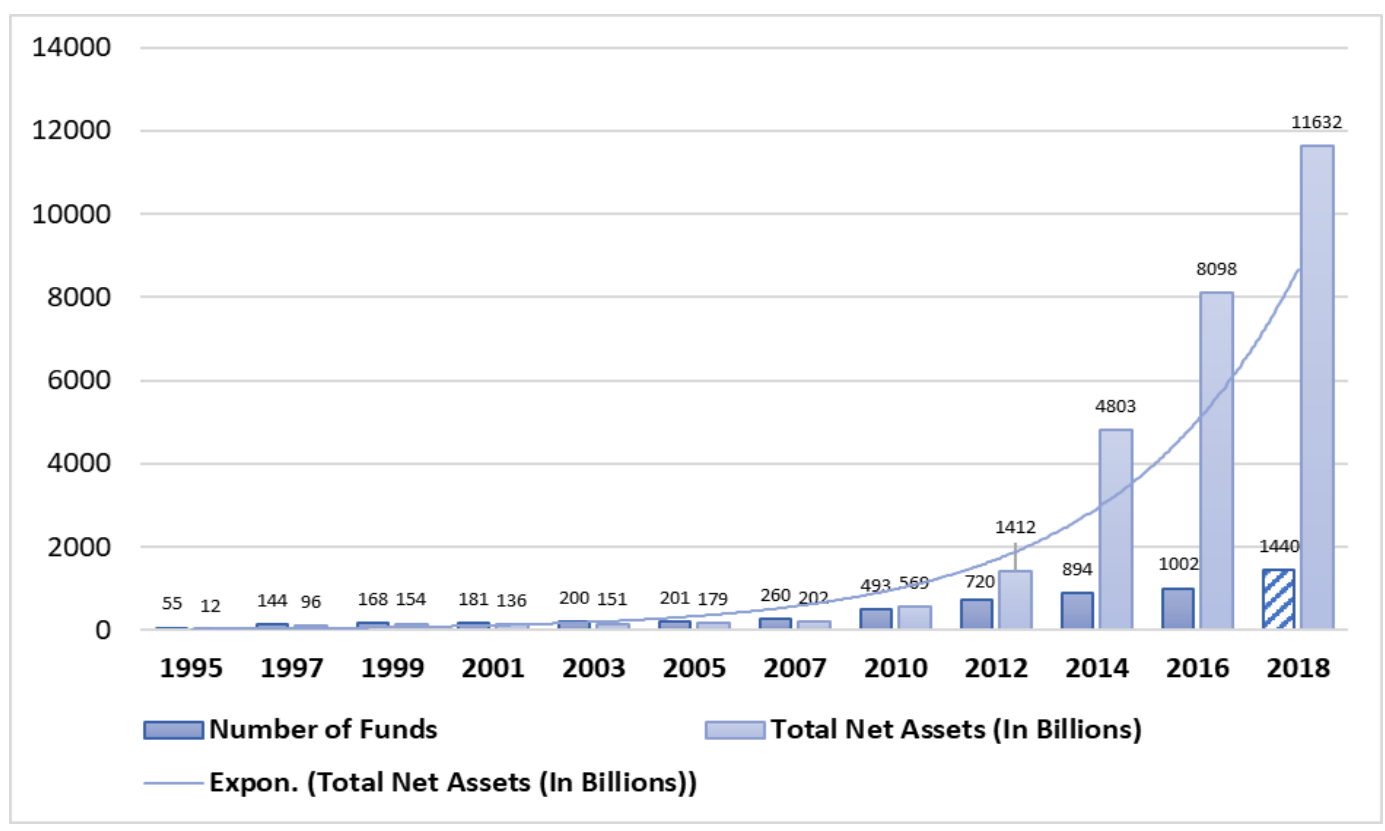

Source: Data from US SIF Foundation, www.ussif.org/files/SIF_Trends_16_Executive_Summary(1).pdf, 2016, p14, updated with https://www.ussif.org/fastfacts, Aug 2019. Number of funds in 2018 estimated based on trend in total net assets. Note: ESG funds include mutual funds, variable annuity funds, closed-end funds, exchangetraded funds, alternative investment funds and other pooled products, but exclude separate accounts.

Figure 2: Growth of Sustainable Investing Assets by Region 2014 - 2018, GSI Alliance

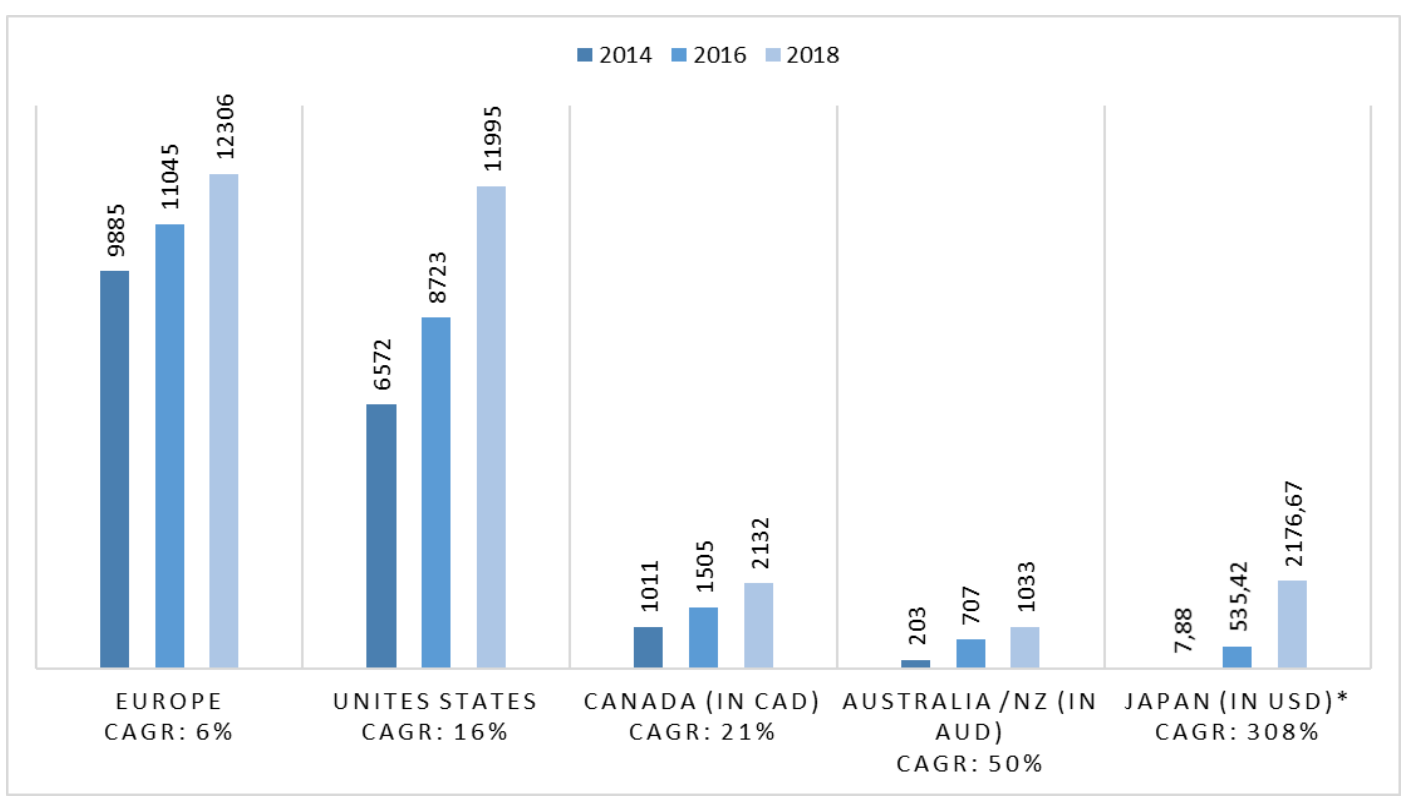

Source: Data from Global Sustainable Investing Alliance (2018) 2018 Global Sustainable Investment Review, p.8. Online under http://www.gsi-alliance.org/wp-content/uploads/2019/06/GSIR_Review2018F.pdf, last accesses Aug 2019. *Conversion of Yes to USD on daily rate from 19.08.2019: 1/0.0094. 


\section{Figure 3: Topic of KLD Articles by Percentage and Year}

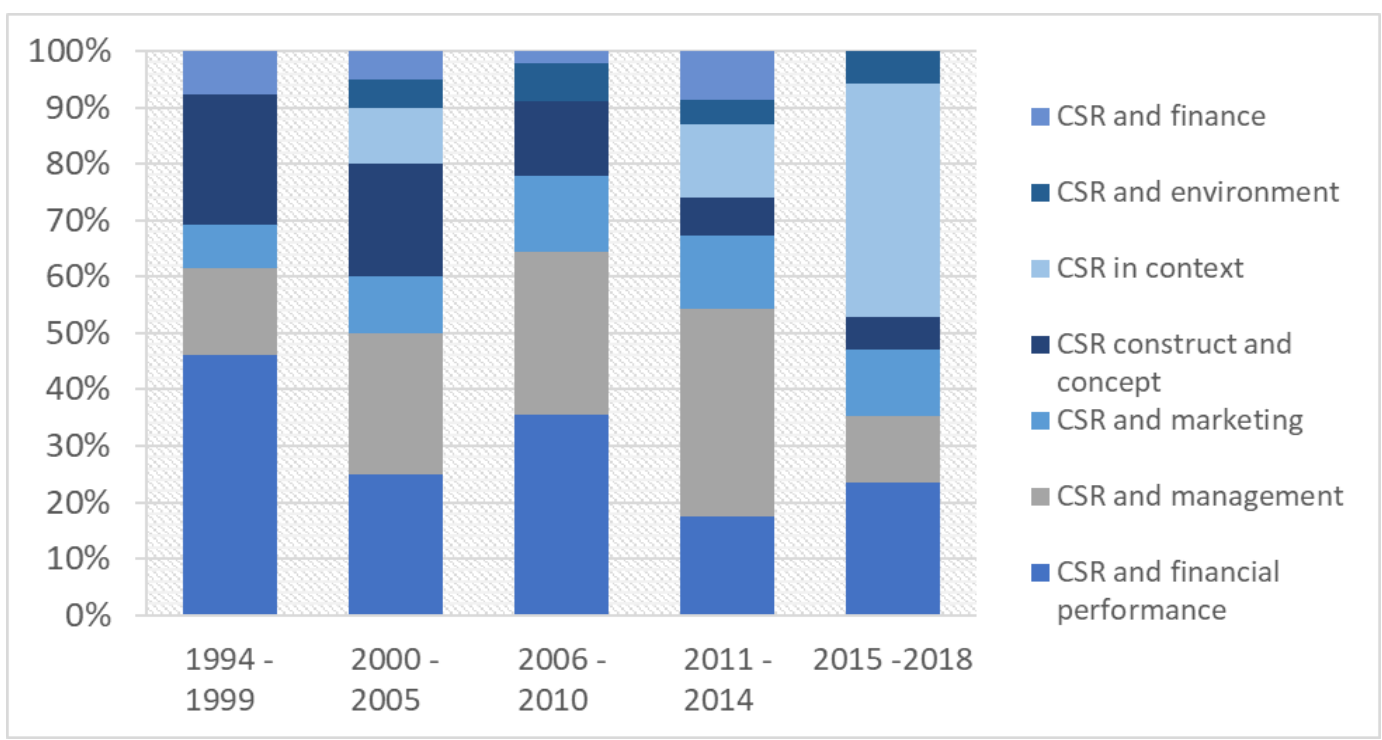

Source: Journal articles mined from Google Scholar, first 10 pages of search term "KLD data" and first three pages of the same search term with extra filter "after 2016 ".

\section{Figure 4: Type of Journal publishing KLD article, by absolute Number and Year}

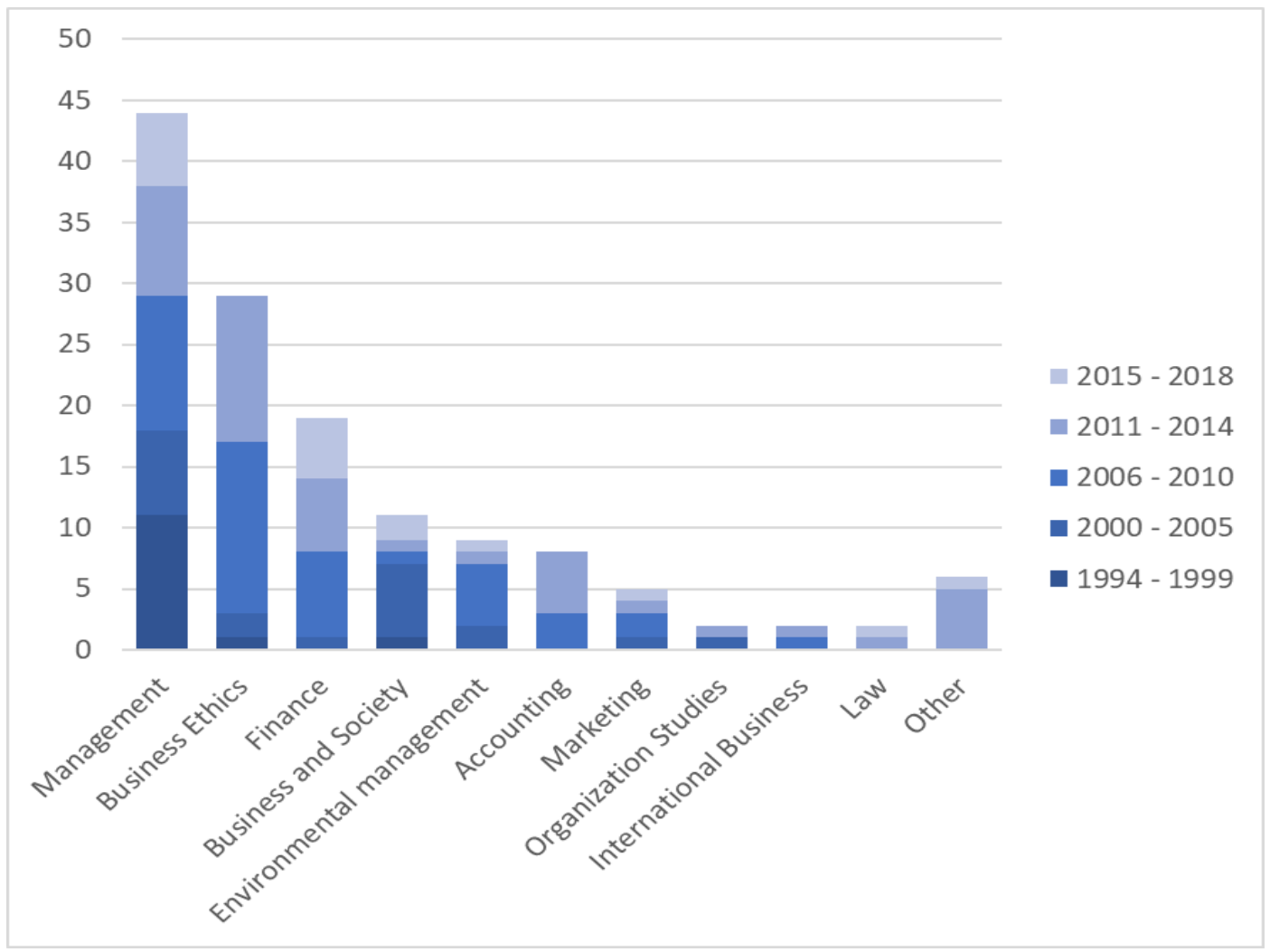

Source: Journal articles mined from Google Scholar, first 10 pages of search term "KLD data" and first three pages of the same search term with extra filter "after 2016". "Other" journals include informatics, psychology, economics, technology and innovation, and research policy. Journals are listed in Appendix table A1 and A2. 
Table 1: List of Interviews

Name

Title

Steve Lydenberg

Hewson Baltzell

Matthew Kiernan

Linda-Eling Lee
Co-Founder and CEO

Co-Founder and CEO

Co-Founder and CEO

Global Head of ESG

Research
Organization

Date(s) Interviewed

Kinder, Lydenberg and Domini Research Ltd. May 2018 / July 2019

Innovest Strategic Value Advisors

July 2019

Innovest Strategic Value Advisors

MSCI ESG Research
July 2019

May 2018 / Aug 2018 
Table 2: Sequence of Acquisitions from RiskMetrics to MSCI

\begin{tabular}{|c|c|c|}
\hline YEAR & Event & Detail \\
\hline 1994 & Creation of RiskMetrics & J.P. Morgan's internal value-at-risk program \\
\hline 2005 & ISS acquires IRRC & The Investor Responsibility Research Center becomes the E\&S component of ISS \\
\hline 2007, Jan & RiskMetrics acquires ISS & Institutional Shareholder Services Inc. \\
\hline 2007, Aug & RiskMetrics acquires CFRA & Center for Financial Research and Analysis \\
\hline 2008, Oct & RiskMetrics acquires Applied4 Technology & $\begin{array}{l}\text { Specialist provider of technology solutions in the field of investment performance } \\
\text { measurement. }\end{array}$ \\
\hline 2009, Feb & RiskMetrics acquires Innovest & Joins the original E\&S team from ISS in evaluating ESG matters \\
\hline 2009, Nov & RiskMetrics acquires KLD & Alternate methodological approach to Innovest \\
\hline 2010, June & MSCI acquires RiskMetrics & With it Innovest, KLD, CFRA and ISS \\
\hline 2012, Nov & MSCI acquires IPD & IPD Real estate performance measurement group \\
\hline 2013, Jan & MSCI acquires InvestorForce & Performance reporting tools to the U.S. institutional investment community \\
\hline 2013, March & MSCI sells CFRA & Center for Financial Research and Analysis is sold to private investor \\
\hline 2014, April & MSCI sells ISS & Becomes independent again, since 2018 known as ISS-oekom \\
\hline 2014, Aug & MSCI acquires GMI Ratings & Provider of corporate governance research and ratings \\
\hline 2015, Oct & MSCI acquires Insignis & Provider of automated collection, aggregation and management of financial data \\
\hline
\end{tabular}


Table 3: Topics in Articles Using KLD Data for Analysis.

\begin{tabular}{|c|c|c|c|c|c|c|}
\hline $\begin{array}{c}\text { CSR and financial } \\
\text { performance }\end{array}$ & $\begin{array}{c}\text { CSR and } \\
\text { management }\end{array}$ & $\begin{array}{c}\text { CSR and } \\
\text { marketing }\end{array}$ & $\begin{array}{c}\text { CSR construct and } \\
\text { concept }\end{array}$ & $\begin{array}{l}\text { CSR in } \\
\text { context }\end{array}$ & $\begin{array}{c}\text { CSR and } \\
\text { environment }\end{array}$ & $\begin{array}{l}\text { CSR and } \\
\text { finance }\end{array}$ \\
\hline $\begin{array}{l}\text { E.g., CSR and } \\
\text { shareholder value and } \\
\text { returns, portfolio } \\
\text { performance, firm } \\
\text { value and performance, } \\
\text { etc. }\end{array}$ & $\begin{array}{l}\text { E.g., CSR and executive } \\
\text { compensation, } \\
\text { management incentives, } \\
\text { strategic decisions, } \\
\text { leadership, } \\
\text { risks, etc. }\end{array}$ & $\begin{array}{c}\text { E.g., CSR and } \\
\text { reputation, media } \\
\text { attention, consumer } \\
\text { awareness, employer } \\
\text { branding, labor, etc. }\end{array}$ & $\begin{array}{l}\text { E.g., CSR construct } \\
\text { validity, theoretical } \\
\text { conceptualization, } \\
\text { measurement accuracy, } \\
\text { etc. }\end{array}$ & $\begin{array}{c}\text { E.g., CSR in } \\
\text { controversial industries, } \\
\text { special sectors, in times } \\
\text { of crises, political } \\
\text { activities, etc. }\end{array}$ & $\begin{array}{l}\text { E.g., CSR and environ- } \\
\text { mental performance, } \\
\text { environ-mental } \\
\text { disclosure, legitimacy, } \\
\text { etc. }\end{array}$ & $\begin{array}{l}\text { E.g., social investing, } \\
\text { green bond market, } \\
\text { CSR and cost of } \\
\text { capital, institutional } \\
\text { investors' role, etc. }\end{array}$ \\
\hline
\end{tabular}

Source: List of journal topics compiled by authors. 
Table 4: Summary of Sample Studies and Their Methodologies Used in Assessing KLD.

\begin{tabular}{|c|c|c|c|c|}
\hline $\begin{array}{l}\text { Authors } \\
\text { /Year }\end{array}$ & Title & Journal & Methodology & Dependent Variable \\
\hline $\begin{array}{l}\text { Mahoney } \\
\text { and } \\
\text { Roberts } \\
2009\end{array}$ & $\begin{array}{l}\text { Corporate Social } \\
\text { Performance (CSP), } \\
\text { financial performance and } \\
\text { institutional ownership in } \\
\text { Canadian firms }\end{array}$ & $\begin{array}{l}\text { Accounting } \\
\text { Forum }\end{array}$ & $\begin{array}{l}\text { Using a composite measure of CSP: "This variable is measured by summing all } \\
\text { dimension strength ratings and subtracting all dimension weaknesses ratings to } \\
\text { create a composite CSP score. Investigating the effects of individual dimension } \\
\text { variables within the KLD databases by also using the net of the strength and } \\
\text { weakness ratings for each of the dimensions as separate independent variables". }\end{array}$ & $\begin{array}{l}\text { Financial performance: } \\
\text { return on assets (ROA) and } \\
\text { return on equity (ROE) each } \\
\text { with one-year lag. }\end{array}$ \\
\hline $\begin{array}{l}\text { Ruf et al. } \\
2001\end{array}$ & $\begin{array}{l}\text { An empirical investigation } \\
\text { of the relationship between } \\
\text { change in CSP and financial } \\
\text { performance: A stakeholder } \\
\text { theory perspective }\end{array}$ & $\begin{array}{l}\text { Journal of } \\
\text { Business } \\
\text { Ethics }\end{array}$ & $\begin{array}{l}\text { Aggregate score with weights: "To assess the relative importance of the eight KLD } \\
\text { social performance dimensions, a questionnaire was sent to } 400 \text { social investors and } \\
\text { the dimensions were weighted accordingly in the aggregation of the data to a } \\
\text { composite score: Five of the eight dimensions (product liability, community } \\
\text { relations, environmental protection, women's and minority issues, and employee } \\
\text { relations) are rated on a } 5 \text { point scale }(-2 \text { to }+2) \text {, while the other three dimensions are } \\
\text { rated on three point scale ( }-2 \text { to } 0) \text {." The scores are weighted and summed up. }\end{array}$ & $\begin{array}{l}\text { Financial performance: } \\
\text { return on equity (plus one- } \\
\text { year lag), return on sales, and } \\
\text { growth in sales }\end{array}$ \\
\hline $\begin{array}{l}\text { Chen et al. } \\
2018\end{array}$ & $\begin{array}{l}\text { How business strategy in } \\
\text { non-financial firms } \\
\text { moderates the curvilinear } \\
\text { effects of CSR and } \\
\text { irresponsibility on corporate } \\
\text { financial performance }\end{array}$ & $\begin{array}{l}\text { Journal of } \\
\text { Business } \\
\text { Research }\end{array}$ & $\begin{array}{l}\text { Two independent variables were included, corporate social responsibility (CSR) and } \\
\text { corporate social irresponsibility (CSiR), which were both constructed by using the } \\
\text { KLD database. As a result, the CSR score was the sum of KLD strengths rated across } \\
\text { the seven attributes, The CSiR score was the total amount rated by KLD concerns. } \\
\text { This study, further, squared the CSR and CSiR scores to test the hypothesized } \\
\text { curvilinear relationships. }\end{array}$ & $\begin{array}{l}\text { Financial performance: } \\
\text { net income, calculated as } \\
\text { revenues adjusted by interest, } \\
\text { taxes, depreciation and } \\
\text { amortization in a given year t. }\end{array}$ \\
\hline $\begin{array}{l}\text { Vans Lins } \\
\text { et al. } \\
2017\end{array}$ & $\begin{array}{l}\text { Social Capital, Trust, and } \\
\text { Firm Performance: The } \\
\text { Value of Corporate Social } \\
\text { Responsibility } \\
\text { during the Financial Crisis }\end{array}$ & $\begin{array}{l}\text { The Journal } \\
\text { of Finance }\end{array}$ & $\begin{array}{l}\text { Exclusion of governance and product categories. Net CSR measure: adding strengths } \\
\text { and subtracts concerns. As the maximum number of strengths and concerns for any } \\
\text { given category varies over time, authors scale the strengths (concerns) for each } \\
\text { category by dividing the number of strengths (concerns) for each firm-year by the } \\
\text { maximum number of strengths (concerns) possible for that category in that year. The } \\
\text { resulting strength and concern indices range from zero to one. The measure of net } \\
\text { CSR involvement is then obtained by subtracting the concerns index from the } \\
\text { strengths index. The net CSR index per category therefore ranges from }-1 \text { to }+1 \text {. } \\
\text { Finally, to obtain our primary explanatory variable, a firm's total net CSR index, the } \\
\text { net CSR indices for the categories of community, diversity, employee relations, } \\
\text { environment, and human rights are combined. The final scale is a net measure across } \\
\text { a set of stakeholder-oriented categories, and ranges from }-5 \text { to }+5 \text {. }\end{array}$ & $\begin{array}{l}\text { Raw Crisis-Period Return, } \\
\text { which is the firm's raw buy- } \\
\text { and-hold return from August } \\
2008 \text { through March } \\
2009 \text {, and Abnormal Crisis- } \\
\text { Period Return, which is the } \\
\text { raw return minus the expected } \\
\text { return, based on a } 60 \text {-month } \\
\text { market model. }\end{array}$ \\
\hline
\end{tabular}




\section{Appendix}

Table A1: Absolute number of compiled KLD-Articles per Academic Journal

\begin{tabular}{|c|c|c|c|}
\hline Name of Journal & $\#$ & Name of Journal & \# \\
\hline JBE & 29 & International Journal of Management & 1 \\
\hline Business and Society & 10 & International Journal of Management Reviews & 1 \\
\hline Strategic Management Journal & 9 & International journal of production research & 1 \\
\hline Academy of Management Journal & 7 & Issues in Social and Environmental Accounting & 1 \\
\hline Academy of Management Proceedings & 4 & Journal of Accounting and Public Policy & 1 \\
\hline Working paper & 4 & Journal of Applied Corporate Finance & 1 \\
\hline CSR and Environmental Management & 3 & Journal of Business Finance and Accounting & 1 \\
\hline Journal of Banking and Finance & 3 & Journal of consumer psychology & 1 \\
\hline Journal of Financial Economics & 3 & Journal of Corporate Finance & 1 \\
\hline Journal of Management & 3 & Journal of Economic Analysis and Policy & 1 \\
\hline The Accounting Review & 3 & Journal of Economics and Management Strategy & 1 \\
\hline Academy of Management Review & 2 & Journal of International Business Studies & 1 \\
\hline Accounting, Organizations and Society & 2 & Journal of Management Development & 1 \\
\hline Business Strategy and the Environment & 2 & Journal of Management Studies & 1 \\
\hline Ecological Economics & 2 & Journal of Managerial Issues & 1 \\
\hline Finance Research Letters & 2 & Journal of Marketing Research & 1 \\
\hline Financial Management & 2 & Journal of Public Policy and Marketing & 1 \\
\hline International journal of law and management & 2 & Journal of Strategy and Management & 1 \\
\hline Journal of Business Research & 2 & Journal of technology management and innovation & 1 \\
\hline Journal of Marketing & 2 & Management Science & 1 \\
\hline The Journal of Finance & 2 & MIT Sloan Management Review & 1 \\
\hline Accounting Forum & 1 & Organization and Environment & 1 \\
\hline Administrative Science Quarterly & 1 & Organization Studies & 1 \\
\hline AIS Electronic Library & 1 & $\begin{array}{l}\text { Presentation at the Academy of Management } \\
\text { Meetings }\end{array}$ & 1 \\
\hline Asia-Pacific Journal of Financial Studies & 1 & $\begin{array}{l}\text { Proceedings of the International Association for } \\
\text { Business and Society }\end{array}$ & 1 \\
\hline California Management Review & 1 & Production and Operations Management & 1 \\
\hline Corporate Governance & 1 & Research Policy & 1 \\
\hline Corporate Reputation Review & 1 & Review of Quantitative Finance and Accounting & 1 \\
\hline Critical perspectives on Accounting & 1 & Social Responsibility Journal & 1 \\
\hline ECGI Finance Working Paper & 1 & Telecommunications Policy & 1 \\
\hline European Financial Management & 1 & The Leadership Quarterly & 1 \\
\hline Financial Analysts Journal & 1 & Tourism Management & 1 \\
\hline
\end{tabular}

Source: compiled from Google Scholar. First ten pages of results for search term: "KLD data" and first three pages of results for search term "KLD data" and filter "after 2016". 
Table A2: Descriptives of KLD-Articles by Year and Cluster

\begin{tabular}{lllllll}
\hline JOURNALS & & & & & & \\
CLUSTER & $\mathbf{1 9 9 4}-$ & $\mathbf{2 0 0 0}-$ & $\mathbf{2 0 0 6}-$ & $\mathbf{2 0 1 1} \boldsymbol{-}$ & $\mathbf{2 0 1 5}$ - & Total \\
& $\mathbf{1 9 9 9}$ & $\mathbf{2 0 0 5}$ & $\mathbf{2 0 1 0}$ & $\mathbf{2 0 1 4}$ & $\mathbf{2 0 1 8}$ & \\
\hline Management & 11 & 7 & 11 & 9 & 6 & $\mathbf{4 4}$ \\
Business Ethics & 1 & 2 & 14 & 12 & 0 & $\mathbf{2 9}$ \\
Finance & 0 & 1 & 7 & 6 & 5 & $\mathbf{1 9}$ \\
Business and Society & 1 & 6 & 1 & 1 & 2 & $\mathbf{1 1}$ \\
Environmental management & 0 & 2 & 5 & 1 & 1 & $\mathbf{9}$ \\
Accounting & 0 & 0 & 3 & 5 & 0 & $\mathbf{8}$ \\
Marketing & 0 & 1 & 2 & 1 & 1 & $\mathbf{5}$ \\
Working paper & 0 & 0 & 1 & 3 & 0 & $\mathbf{4}$ \\
Organization Studies & 0 & 1 & 0 & 1 & 0 & $\mathbf{2}$ \\
International Business & 0 & 0 & 1 & 1 & 0 & $\mathbf{2}$ \\
Law & 0 & 0 & 0 & 1 & 1 & $\mathbf{2}$ \\
Other (below) & 0 & 0 & 0 & 5 & 1 & $(6)$ \\
$\quad$ Informatics & 0 & 0 & 0 & 0 & 1 & $\mathbf{1}$ \\
$\quad$ Psychology & 0 & 0 & 0 & 1 & 0 & $\mathbf{1}$ \\
$\quad$ Economics & 0 & 0 & 0 & 1 & 0 & $\mathbf{1}$ \\
$\quad$ Tech and Innovation & 0 & 0 & 0 & 1 & 0 & $\mathbf{1}$ \\
$\quad$ Research Policy & 0 & 0 & 0 & 1 & 0 & $\mathbf{1}$ \\
$\quad$ Social Responsibility & 0 & 0 & 0 & 1 & 0 & $\mathbf{1}$ \\
& & & & & & \\
\hline & $\mathbf{1 3}$ & $\mathbf{2 0}$ & $\mathbf{4 5}$ & $\mathbf{4 6}$ & $\mathbf{1 7}$ & $\mathbf{1 4 1}$
\end{tabular}




\section{ENDNOTES}

${ }^{\mathrm{i}}$ Robert G. Eccles is a Visiting Professor of Management Practice at Saïd Business School, Oxford University and was the founding chairman of the Sustainability Accounting Standards Board (SASB).

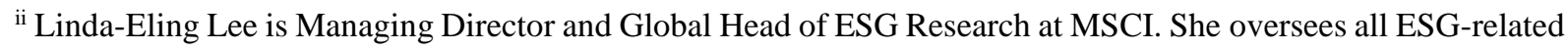
content and methodology and chairs MSCI's ESG Methodology Committee. She leads one of the largest research teams in the world dedicated to identifying risks and opportunities arising from material ESG issues. Linda received her PhD in Organizational Behavior and B.A. from Harvard University, as well as her M.St. from Oxford University.

iii Corresponding author. Judith C. Stroehle is a Postdoctoral Fellow at the Responsible Business Hub at Said Business School, Oxford University. She received her PhD in Economic Sociology from the University of Milan. Contact: judith.stroehle@sbs.ox.ac.uk.

iv Although some organizations have emerged to address the diversity in ESG measurement - particularly the Sustainability Accounting Standards Board (SASB) and the Global Reporting Initiative (GRI) - there are no truly universal standards of measurement companies can refer to.

" Social construction is understood as the process of giving "meaning" to social facts or, as in this case, measures. In the accounting literature, defining work describes how the influence of societal values, belief systems, institutions, and power dynamics can all play an important role in the process of creating measures that ensure intersubjectivity that allow for social and market interaction (Richardson, 1987; Burchell, et al. 1980).

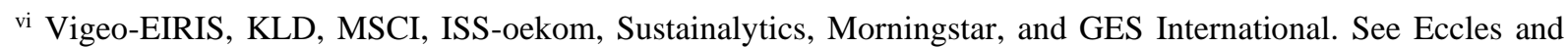
Stroehle (2018).

${ }^{\text {vii }}$ KLD stands for Kinder, Lydenberg, and Domini.

viii For early faith-based organizations, such as the Quaker Friends Fiduciary Corporation, these restrictions required the avoidance of "sin-stocks," a policy that reflected their decision in 1898 to adopt a "no weapons, alcohol or tobacco" investment policy designed to align their investment funds with their core values (Roselle, 2016).

${ }^{\text {ix }}$ EIRIS is today part of the French data vendor Vigeo-EIRIS; the two companies merged in 2015.

${ }^{x}$ https://web.archive.org/web/20000303163945/http://www.eiris.org:80/, archived URL. Last accessed Apr 2018.

${ }^{\text {xi }}$ https://www.unglobalcompact.org/docs/issues_doc/Financial_markets/who_cares_who_wins.pdf, last accessed August 2018 
xii Our objective in preparing this report was to answer the following question put to us by the Asset Management Working Group: 'Is the integration of environmental, social and governance issues into investment policy (including asset allocation, portfolio construction and stock-picking or bond-picking) voluntarily permitted, legally required or hampered by law and regulation; primarily as regards public and private pension funds, secondarily as regards insurance company reserves and mutual funds?'. In section "purpose and scope" of the Freshfield Report 2005 http://www.unepfi.org/fileadmin/documents/freshfields_legal_resp_20051123.pdf, last accessed August 2018

xiii www.forbes.com/sites/georgkell/2018/07/11/the-remarkable-rise-of-esg/\#5e36dbaa1695, accessed Aug 2018

${ }^{\text {xiv }}$ The six Principles for Responsible Investment are a voluntary and aspirational set of investment principles that offer a menu of possible actions for incorporating ESG issues into investment practice. https://www.unpri.org/, last accessed August 2018

${ }^{\mathrm{xv}}$ Number reported under https://www.unpri.org/annual-report-2018/how-we-work/the-pri-in-numbers, Signatory breakdown by asset and AUM.

${ }^{\text {xvi }}$ In 2018, the GSIR has brought their global ratings and rankings library under the umbrella of "The Reporting Exchange", where all data is now hosted. See https://www.reportingexchange.com/, last accessed Aug 2019.

xvii https://www.forbes.com/sites/georgkell/2018/07/11/the-remarkable-rise-of-esg/\#5e36dbaa1695. In the United States this was an estimated U.S.\$ 8.72 trillion in 2016, which is about one-fifth of all investment under professional management. See www.ussif.org/files/SIF_Trends_16_Executive_Summary(1).pdf, last accessed August 2018.

xviii The values- versus value-driven investor juxtaposition has been used for a long time in the ESG debate, going back to the UNEP-FI Freshfield Report, which framed ESG mainly for financial risk management and distinguished between value- and values-driven investment by exploring ESG considerations as matters of fiduciary duty: "ESG considerations are capable of affecting investment decision-making in two distinct ways: they may affect the financial value to be ascribed to an investment as part of the decision-making process and they may be relevant to the objectives that investment decision-makers pursue" (UNEP-FI 2005 Freshfield Report p.10, emphasis added)

${ }^{\text {xix }}$ Much has been written on the origins of financial accounting and the role of materiality in it. See Andrew A. Acito, Jeffrey J. Burks, and W. Bruce Johnson (2009) Materiality Decisions and the Correction of Accounting Errors. The Accounting Review: May 2009, Vol. 84, No. 3, pp. 659-688 or Edgley, Carla (2013) A genealogy of accounting materiality for a comprehensive discussion on the topic. 
${ }^{\mathrm{xx}}$ Sustainability Accounting Standard Board. SASB's Approach to Materiality for the Purpose of Standards Development. See online http://library.sasb.org/wp-content/uploads/2017/01/ApproachMateriality-Staff-Bulletin01192017.pdf?hsCtaTracking=9280788c-d775-4b34-8bc8-5447a06a6d38\%7C2e22652a-5486-4854-b68f-

73fea01a2414, last accessed August 2018.

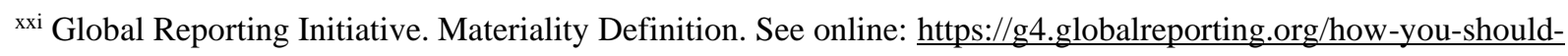
report/reporting-principles/principles-for-defining-report-content/materiality/Pages/default.aspx, last accessed August 2018.

xxii As defined by the United Nations as "development that meets the needs of the present without compromising the ability of future generations to meet their own needs" http://www.unepfi.org/about/unep-fi-statement/, last accessed August 2018.

xxii As defined by the GRI: "Organizations are faced with a wide range of topics on which they could report. Relevant topics are those that may reasonably be considered important for reflecting the organization's economic, environmental and social impacts, or influencing the decisions of stakeholders." https://g4.globalreporting.org/ how-you-should-report/reporting-principles/principles-for-defining-report-content/materiality/Pages/default.aspx last accessed August 2018.

${ }^{\text {xxiv }}$ As defined by SASB: "Standards address the sustainability topics that are reasonably likely to be material and to have material impacts on the financial condition or operating performance of companies in an industry". https://www.sasb.org/materiality/important/, last accessed August 2018.

xxv web.archive.org/web/20050403203540/http://www.kld.com:80/about/mission.html, last accessed April 2018. xxvi web.archive.org/web/20070524034938/http://www.kld.com:80/about/index.html, last accessed April 2018. xxvii With political changes over time, these dimensions evolved, excluding, for example, investments in South Africa after the abolishment of Apartheid around 1995.

xxviii http://web.archive.org/web/20060319043039/http://www.kld.com/research/methodology.html, last accessed September 2018. A comprehensive list of all issues screened within these categories can be found under http://web.archive.org/web/20101223075727/http://www.kld.com:80/research/ratings_indicators.html.

${ }^{\text {xxix }}$ Shortly prior to the acquisition of KLD by RiskMetrics, in June 2009, KLD had developed an aggregate score, in an attempt to meet the market demand for an ESG aggregate rating. This data series was nascent and shortlived and was hence not part of the historical KLD data files that have been widely used.

xxx www.csrwire.com/press releases/23136-KLD-Launches-Global-Sustainability-Index-GSI-, last accessed April 2018.

${ }^{x \times x i}$ https://www.marketwatch.com/story/domini-400-soģigl-index-goes-live, last accessed Aug 2019. 
xxxii https://web.archive.org/web/20000620224819/http://www.innovestgroup.com:80/about_1.html, archived URL, last accessed August 2018.

xxxiii Wall Street Journal (Sunday, July 19 ${ }^{\text {th }}$, 1998) "For Wall Street, Increasing Evidence That Green Begets Green", by Claudia Deutch.

xxxiv https://web.archive.org/web/20000620224819/http://www.innovestgroup.com:80/about_1.html, archived URL, last accessed August 2018.

xxxv https://web.archive.org/web/19981203133552/http://www.innovestgroup.com:80/, archived website from 1998, last accessed August 2018.

xxxvi https://web.archive.org/web/20060113092308/http://www.innovestgroup.com:80/, archived website from 2006, last accessed August 2018.

${ }^{\text {xxxvii }}$ AAA (best) - AA - A - BBB (average) - BB - B - CCC (worst) $-\mathrm{CC}-\mathrm{C}$.

xxxviii The "Iceberg Balance Sheet": "As we move deeper and deeper into the era of knowledge-value, and intangibles, conventional balance sheets and profit and loss statements will capture and reflect less and less of a company's true value and competitive potential. What is needed instead is a new, more dynamic "iceberg balance sheet" approach, one which focuses investor and senior management attention where it belongs: on the roughly $85 \%$ of companies' true value which cannot be explained by traditional, accounting-driven securities analysis. In point of fact, it is the unseen part of the "value iceberg", the much larger portion below the surface, which contains the primary drivers of the company's future value-creation capabilities and unique comparative advantage. These intangible value drivers are of course notoriously elusive and difficult to measure, but they are absolutely central to companies' competitiveness and profitability going forward". Archived website from 2006 under https://web.archive.org/web/20060113092308/http://www.innovestgroup.com:80/, last accessed August 2018.

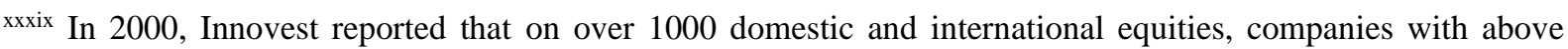
average EcoValue ' $21^{\mathrm{TM}}$ ratings had "consistently outperformed lower rated companies by 300 to 2500 basis points per year." See web.archive.org/web/20000623141456/http://www.innovestgroup.com:80/index.html, last accessed August 2018.

xl https://www.kellogg.northwestern.edu/faculty/mazzeo/htm/sp_files/021209/(4)\%20Innovest/Innovest\%20 Publications/Portfolio_Simulation_4-03_Exec_Sum.pdf, last accessed August 2018.

xli RiskMetrics was "born" in 1994 as an internal function within JP Morgan that developed a VAR model, producing the "4:15 report" that measured end of day portfolio risk. The RiskMetrics methodology was then published, became a standard and was developed into a software product in 1996. Two years later, RiskMetrics 
was spun out of JP Morgan as a separate company. See online archive of company history under https://web.archive.org/web/20091210103151/http://www.riskmetrics.com:80/history, last accessed Aug 2018.

xlii Institutional Shareholder Services (ISS) was founded in 1985 with the goal to promote good corporate governance in the private sector and raise the level of responsible proxy voting among institutional investors and pension fund fiduciaries. In 1986, ISS launched its Proxy Advisory Service to assist institutional investors in fulfilling their fiduciary obligations with comprehensive proxy analysis. RiskMetrics Group acquired ISS in January 2007. https://web.archive.org/web/20091210103151/http://www.riskmetrics.com:80/history, last accessed Aug 2018.

xliii CFRA was founded in 1994 to provide institutional investors with early warning signs of business deterioration within portfolio companies. CFRA built a rigorous and proprietary forensic accounting research process for assessing the quality and sustainability of companies' reported financial results and expanded into specialty legal, regulatory and due diligence research. RiskMetrics Group acquired CFRA in August 2007. https://web.archive.org/web/20091210103151/http://www.riskmetrics.com:80/history, last accessed Aug 2018. ${ }^{\text {xliv }}$ MSCI ESG KLD STATS 1991-2016 Methodology Document (March 2017) states, in bold, on page 14: "Please note, that the industry-based key issue ratings model was introduced to MSCI ESG KLD STATS in 2010. Therefore, for the STATS-2010 Data Set and after, all companies in the coverage universe are only assessed for a limited set of positive ESG indicators. Each indicator that is not researched for a company will have an "NR" for "Not Researched". Prior to STATS - 2010 Data Set, all of the positive ESG performance indicators were researched for all of the companies in the coverage universe."

xlv The database includes five universes (Universe A - E), each of which has a specific timeframe and coverage. Universe B and C have been discontinued in 2014. See MSCI ESG KLD STATS: 1991 - 2016 Data sets Methodology, from March 2017.

xlvi We chose to use the term "Corporate Social Responsibility" here as most of the examined articles work with this. In current discussion, this term has somewhat been replaced by "Corporate Sustainability", but some also use "Corporate Social Performance". All of these concepts are different from ESG, which simply describes the data aggregation of environmental, social and governance concerns.

xlvii Articles were compiled from those listed on the first 10 pages for the search term "KLD data" and on the first three pages for "KLD data - articles after 2016" and finally the first three pages of "KLD database - articles after 2014”.

xlviii The full list of references can be enquired from the authors. Since Google Scholar usually shows those articles first which have the highest hit-rate, we assume that the3grticles we accumulated are of the higher impact factors. 
This bias serves us well, as we are particularly interested in the concepts and uses of KLD data which are most popular and distributed in the academic community.

xlix 29 of 144 articles were published in Journal of Business Ethics, which marks over $20 \%$ of all articles compiled. However, the journals we found on Google Scholar mostly have a medium to high impact-factor and may thus be somewhat overrepresented in the results of the search machine.

${ }^{1}$ Academic impact factors are indicators to rank journals on a set of dimensions, such as their academic prestige and number of citations. A common source used for the review of impact factors is the Scimago Journal Rank Indicator (or SJR) https://www.scimagojr.com/journalrank, developed by SCImago. This indicator shows the visibility of the journals contained in the Scopus ${ }^{\circledR}$ (Elsevier B.V.) database from 1996. Other known sources are the Journal Citation Reports (or JCR), a product of ISI Web of Knowledge, and the Academic Journal Guide (or AJG) of the Chartered Association of Business Schools https://charteredabs.org/academic-journal-guide-2018view/. All last accessed Sept 2018.

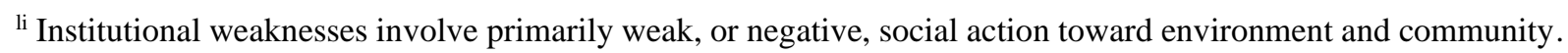
The authors therefore interpreted this type of social action to indicate a firm's neglectful (perhaps even harmful) pattern of action toward institutional stakeholders. Technical weaknesses would, for example, include shortfalls in areas of diversity, employees and products and be especially harmful to stakeholders from the technical environment of the firm (Mattingly and Berman, 2006).

lii In economics, finance, and accounting journals, the average correlations were only about half the magnitude of the findings published in Social Issues in Management, Business Ethics, or Business and Society journals (mean corrected correlation coefficient $\mathrm{p}$ of .22 vs. .49, respectively). Specifically, economists did not find null or negative CSP-CFP correlations, and average findings published in general management outlets $(\mathrm{p}=.41)$ were closer to Social Issues in Management, Business Ethics, and Business and Society results than to findings reported in economics, finance, and accounting journals (Orlitzky, 2011).

liii Yearly dummies as fixed effects can even out differences, but to check for robustness investigators should always make sure that trends and results hold before and after the break in data, and potentially use another data source to test the robustness of their results when using KLD data that crosses 2011. 